\title{
Structural and Optical properties of Some Metals Doped CdO Synthesized by Sol-Gel Method
}

\author{
L.A. Wahab $^{a}$, H.A. Zayed ${ }^{b}$, I.S. Yahia ${ }^{c}$, N.M. Yousif ${ }^{a^{*}}$ \\ ${ }^{a}$ Solid State physics and Accelerators Department in National Center for Radiation Research \\ and Technology, Nasr City, Cairo, Egypt. \\ ${ }^{b}$ PhysicsDepartment in Faculty of women for Art, Sciences, and Education, Ain Shams \\ University, Heliopolis , Cairo, Egypt .. \\ ${ }^{c}$ Department of Physics, Faculty of Science, King Khalid University, P.O. Box 9004, Abha, Saudi \\ Arabia
}

\begin{abstract}
:
Nanoparticles with crystallite size in the range $8.23-27.88 \mathrm{~nm}$ of transition metals (TM= $\mathrm{Cr}, \mathrm{Cu}, \mathrm{Co}, \mathrm{Ni}, \mathrm{Mn}$, and $\mathrm{Fe})$ doped $(\mathrm{CdO})$ films were deposited by the sol-gel spin coating method. The strain, the grain size, lattice parameters and dislocation density were estimated from the XRD patterns. The calculated band gap for $\mathrm{CdO}$ is $2.302 \mathrm{eV}$ and is increased with doping.

Keywords:Metal Oxide Semiconductors, TM- doped CdO, nano-structure, XRD, Spectrophotometer, Optical constants.

Permanent address: thermal and magnetic lab. NCRRT,AEA, Cairo, Egypt.

\section{Introduction:-}

The metal oxide semiconductor materials have attracted much attention owing to their potential applications in electronic and photovoltaic devices. $\mathrm{CdO}$ is an n-type semiconductor with a rock-salt crystal structure (FCC) and possesses a direct band gap of $2.2 \mathrm{eV}$ [Ortega, M., etal., 1765]. High electrical conductivity and high optical transmittance in the visible region of the solar spectrum along with a moderate refractive index of $\mathrm{CdO}$ make it useful for various applications such as solar cells, transparent electrodes, phototransistors, photodiodes, gas sensors, etc [Ferro,R., etal., 2000; Subramanyam, T.K., etal., 1998; Muralia,K.R.,etal.,2010].
\end{abstract}

\section{* Corresponding author:}

N.M.Yousif(NashwaYousif, yousif_nashwa@yahoo.com) 
The electrical and optical properties of $\mathrm{CdO}$ can be tuned through doping with different metals [Deckate, RJ., etal.,2008].

A variety of techniques such as sol-gel [Carballedo-Galicia, DM., etal., 2000], spray pyrolysis [Lokhande, B.J., etal., 2001] , sputtering method [Mastsuura,N., etal., 1997], chemical bath deposition (CBD) [Ortega, M., etal., 1765], Langmuir-Blodgett (LB) deposition [Carballedo-Galicia, DM., etal., 2000], activated reactive evaporation [Ramakrishna Reddy, K.T., 1998] and metal organic chemical vapour deposition (MOCVD) [Zhiyong Zhao, etal., 2002] have been employed to prepare $\mathrm{CdO}$ films.

The sol-gel method has several advantages because of its simplicity, easy control of the film composition, safety, low cost of the apparatus and raw materials [Maity, R., etal., 2006].

In an effort to investigate the enhancement of $\mathrm{CdO}$ properties for more applications, $\mathrm{CdO}$ was doped with transition metal ions with ionic radii smaller than $\mathrm{Cd}^{2+}$ and deposited by the solgel spin coating method. This study concerned with the effect of $\mathrm{Cr}, \mathrm{Cu}, \mathrm{Co}, \mathrm{Ni}, \mathrm{Mn}$ and $\mathrm{Fe}$ doping on the structural and optical parameters of $\mathrm{CdO}$.

\section{Experimental details:}

Thin films of $\mathrm{CdO}$ and $(\mathrm{Cu}, \mathrm{Mn}, \mathrm{Cr}, \mathrm{Ni}, \mathrm{Co}, \mathrm{Fe})$ doped $\mathrm{CdO}$ were fabricated using the sol gel technique. Cadmium acetate, copper acetate, Manganese acetate, chromium Chloride, Nickel acetate, Cobalt acetate and Iron chloride, 2-metoxyethanol and diethanolamine. In a typical synthesis, $0.5 \mathrm{M}$ of cadmium acetate was slowly dissolved in 2-metoxyethanol followed by addition of diethanolamine were used to prepare $\mathrm{CdO}$ films. For doping with $(\mathrm{Cu}, \mathrm{Co}, \mathrm{Ni}, \mathrm{Fe}$, $\mathrm{Mn}$, and $\mathrm{Cr}$ ) to $\mathrm{CdO}$, there salts were added in the above mixture. The prepared mixtures were stirred using a magnetic stirrer at $60^{\circ} \mathrm{C}$ for about $2 \mathrm{~h}$ to obtain clear homogeneous solution and then the solution was kept for aging for $18 \mathrm{~h}$ prior to film deposition. The pure and metals $(\mathrm{Cu}, \mathrm{Co}, \mathrm{Ni}$, $\mathrm{Fe}, \mathrm{Mn}$, and $\mathrm{Cr}$ ) doped $\mathrm{CdO}$ films were deposited on microscopy glasses by the sol-gel spin coating followed by heating at $150^{\circ} \mathrm{C}$ for $10 \mathrm{~min}$ to evaporate the solvent and remove organic residuals. The prepared undoped and doped $\mathrm{CdO}$ films were annealed at $400{ }^{\circ} \mathrm{C}$ for $4 \mathrm{hs}$ in furnace. The transmittance and absorbance properties of the films were taken by spectrophotometer UV/VIS V-670 wavelength range 2600-200 nm. X-ray diffraction (XRD) patterns were obtained with XRD-6000 Shimadzu X-ray diffractometer using $\mathrm{CuK}_{\alpha}$ radiation $\left(\lambda=1.54059 \mathrm{~A}^{\circ}\right)$ in the range 2 between $\left(4\right.$ and $\left.50^{\circ}\right)$.

\section{Results and discussion:}

XRD patterns of the undoped and doped of the investigated $\mathrm{CdO}$ films are shown in Fig.(1). The patterns indicate that all of the investigated films have a polycrystalline structure. 
The interplanar spacing $\left(\mathrm{d}_{\mathrm{hkl}}\right)$ data of the observed peaks and its relative $\mathrm{I} / \mathrm{I}_{\mathrm{o}}$ for the investigated films were compared with JCPDs cards to obtain the system configuration (table (1)).

The grain size, strain, lattice parameter, dislocation density and texture coefficient were estimated from the XRD pattern. The average grain size and strain for the films can be determined using the equation [Gurumurugan, K., 1995]:

$$
\frac{\beta \cos \theta}{\lambda}=\frac{1}{L}+\frac{\varepsilon \sin \theta}{\lambda}
$$

where $\beta=$ FWHW and $\theta$ the Bragg angle, D grain size and $\varepsilon$ is the strain. The plot of ( $\beta$ $\cos \theta / \lambda)$ vs $(\sin \theta / \lambda)$ for the various reflection planes was plotted. The $\mathrm{D}$ and $\varepsilon$ values were determined from the intercept and slope of this graph and given in table (1). The table illustrates that grain size of the investigated thin films are in the nano scale. The grain size of CdO film increased with doping metals.

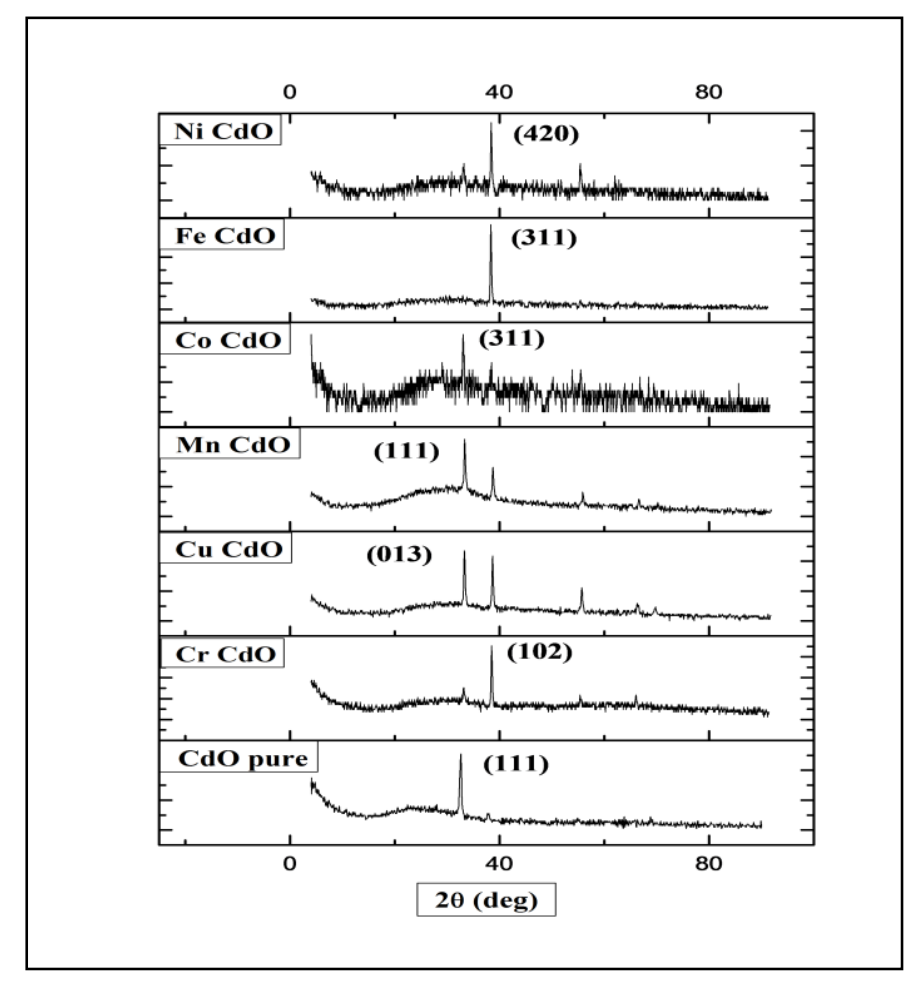

Fig.(1) XRD patterns of undoped and doped Cdo.

The dislocation density values were calculated using the standard relation:

$$
\delta=\frac{n}{L^{2}}
$$

Where (a) is the lattice parameter and (D) is the grain size. The lattice parameter (a) for the investigated films was calculated using the unit cell programme [Holland TJB and RedfernSAT, 1997]. Table (1) illustrates the good agreement between the calculated lattice 
parameter $\left(\mathbf{a}_{\mathbf{e x p}}\right)$ values and the standard $\left(\mathbf{a}_{\mathbf{s}}\right)$. The values of dislocation density are given in table (1).

Table (1) the values of Grain Size, Strain, Dislocation density, and Lattice Parameters of pure and doped $\mathrm{CdO}$.

\begin{tabular}{|c|c|c|c|c|c|c|}
\hline sample & $\begin{array}{c}\text { Grain Size } \\
\text { (D) }, \mathrm{nm}\end{array}$ & Strain $(\varepsilon)$ & $\begin{array}{l}\text { Dilocation } \\
\text { Density }(\delta)\end{array}$ & $\mathbf{a}_{\text {exp }}$ & $a_{s}$ & Card No. \\
\hline CdO pure & 8.23 & $4.21 * 10^{-3}$ & $1.476 * 10^{-2}$ & 4.6831 & 4.695 & $\begin{array}{c}\text { 75-0594 } \\
\text { [Cimino, A., etal., } \\
\text { 1960] } \\
\end{array}$ \\
\hline Co CdO & 12.03 & $2.879 * 10^{-3}$ & $6.909 * 10^{-3}$ & 8.5257 & 8.54 & $\begin{array}{c}52- \\
\text { 1798[Vasambekar,R., } \\
\text { 2001] }\end{array}$ \\
\hline MnCdO & 13.39 & $2.586^{*} 10^{-3}$ & $5.57 * 10^{-3}$ & 4.6461 & 4.659 & $\begin{array}{c}89-5995 \\
\text { [Kusigerski, V., etal., } \\
\text { 1996] }\end{array}$ \\
\hline Ni CdO & 17.005 & $2.037 * 10^{-3}$ & $3.458 * 10^{-3}$ & 10.3613 & 10.43 & $\begin{array}{c}02-0976 \\
\text { [Ferrai, etal., 1935] }\end{array}$ \\
\hline $\mathrm{Cr} \mathrm{CdO}$ & 17.29 & $2.004 * 10^{-3}$ & $3.345 * 10^{-3}$ & 3.016 & 2.974 & $\begin{array}{c}89-6743 \\
\text { [Crotlaz, O., etal., } \\
\text { 1996] }\end{array}$ \\
\hline $\mathrm{Cu} \mathrm{CdO}$ & 18.26 & $1.897 * 10^{-3}$ & $2.9992 * 10^{-3}$ & 3.825 & 3.8 & $\begin{array}{c}45-0554 \\
\text { [Qian, Y., etal., 1994] }\end{array}$ \\
\hline Fe CdO & 27.88 & $1.24 * 10^{-3}$ & $1.286 * 10^{-3}$ & 8.6656 & 8.708 & $\begin{array}{c}79-1155 \\
\text { [Arean, C.O., etal., } \\
\mathbf{1 9 8 8} \text { ] }\end{array}$ \\
\hline
\end{tabular}

It is clear from the table that, as the values of the grain size, increases the values of strain and dislocation density increase for the investigated films.

Thus doping of $\mathrm{CdO}$ with metallic ions of smaller radius (80nm, 83nm,78nm74.5nm,60nm, and73nm) like $\left(\mathrm{Cr}^{2+,} \mathrm{Mn}^{2+,} \mathrm{Fe}^{2+,} \mathrm{Co}^{2+,} \mathrm{Ni}^{2+}\right.$ and $\left.\mathrm{Cu}^{2+}\right)$ than $\mathrm{Cd}^{2+}$ (95nm) can control crystal size[Bhatli, K.P., etal., 2005; Ekambaram, S., etal., 2006; Weast, R.C., 1975; Volbers, N, etal., 2007; Li,L.,etal., 2009].

Fig. (2,a) shows the transmittance spectra of pure $\mathrm{CdO}$ film and doped films. The figure illustrates that the films have nearly $70 \%$ transmittance in the optical region. The transmittance of $\mathrm{CdO}$ film decreases by doping. This decrease in transmittance may be due to the absorbance increase (fig2b) by free carriers. The optical absorption edge was analyzed by the following relationship [Pankova, J.I., 1971]

$$
\alpha h v=A\left(h v-E_{g}\right)^{n}
$$

Where $\mathrm{A}$ is a constant, $\mathrm{h} v$ is the photon energy and $\mathrm{E}_{\mathrm{g}}$ is the optical band gap. Fig (3) shows the plots of $(\alpha h v)^{2}$ vs. hv, the values of $E_{g}$ in table (2) indicate that $E_{g}$ for $\mathrm{CdO}$ increases with the addition of TM. This effect is frequently observed in n-type semiconductors. The change of 
carrier concentration in doped thin films cause the Fermi level move into the conduction band. The filling of the conduction band by electrons generally result in blue shift in the near band edge emission. The shifting in the optical band gap of any material, usually semiconductors, is known as Bursteing-Moss shift due to doping effect. This blue shift may be due to the increase in grain size which leads to widening of the band gap.

Spectral change in the optical absorption near the band edge is characterized by an $\alpha(v)$ that increases exponentially with hv, obeying the exponential relation:

$$
\alpha(v)=\alpha_{0} \exp \left(h v / E_{s}\right)
$$

where $\alpha_{0}$ is a constant and $\mathrm{E}_{\mathrm{s}}$ is interpreted as the width of tails of the localized states in the gap. It represents the degree of disorder [Mustafa Öztas, etal., 2008]. Fig (4) illustrates $\log \alpha$ as a function of hv. $\mathrm{E}_{\mathrm{s}}$ was calculated and given in table (2). It is observed that the addition of TM to $\mathrm{CdO}$ decrease $\mathrm{E}_{\mathrm{s}}$. Since $\mathrm{E}_{\mathrm{s}}$ represents the degree of disorder, adding TM to $\mathrm{CdO}$ decrease the disorder. The decrease of disorder is responsible for the increase of the optical gap.

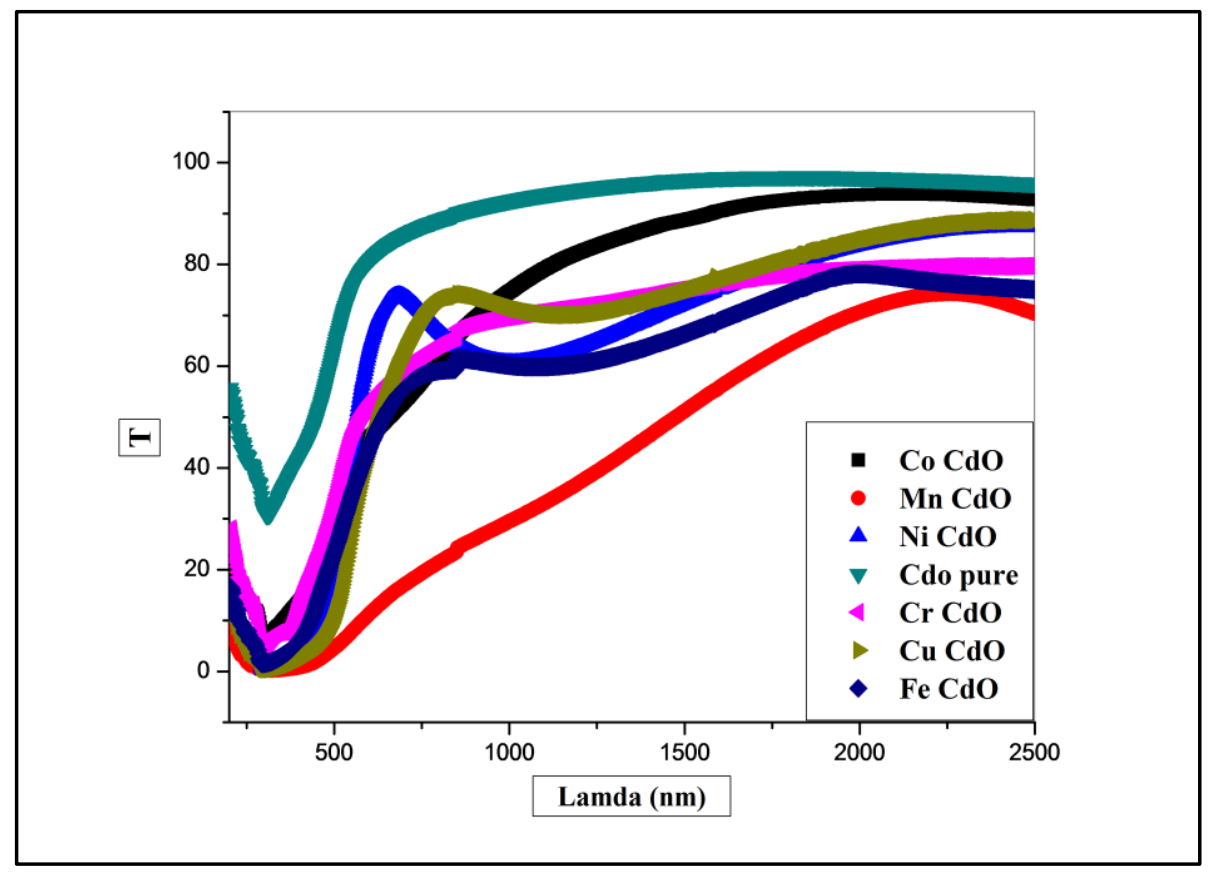

(a)Transmittance of undoped and doped CdO 


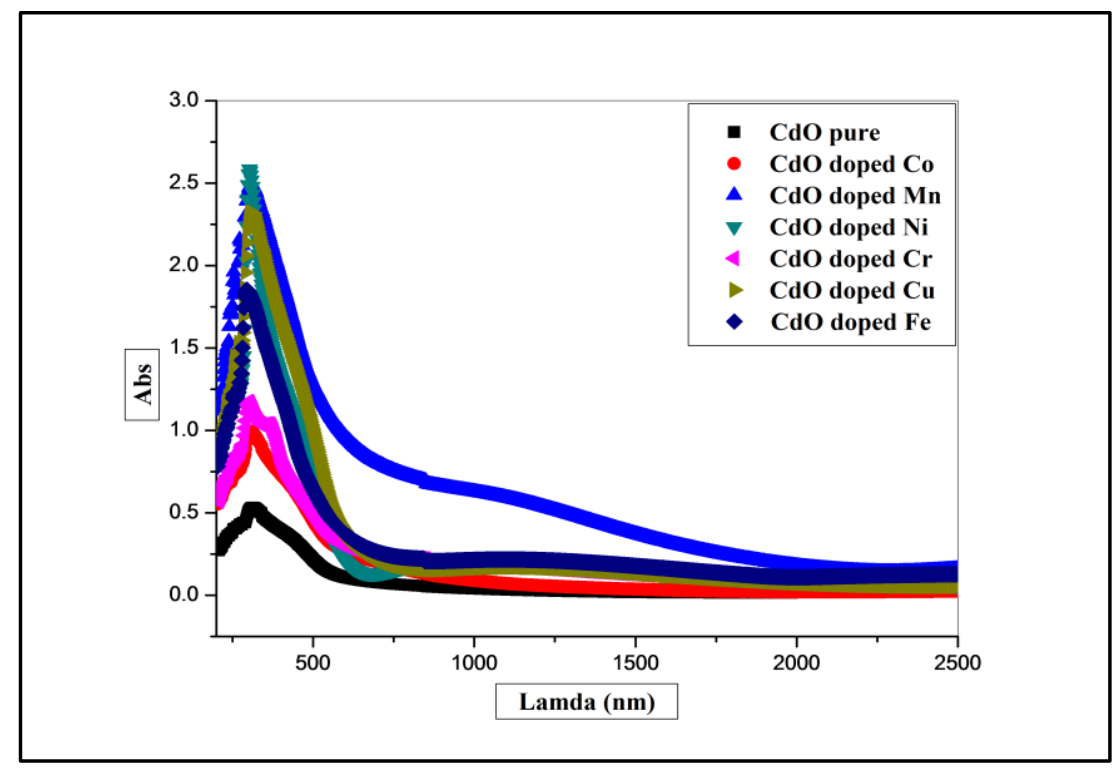

(b)Absorbance of undoped and doped $\mathrm{CdO}$

Fig. $(2(a, b))$ Transmittance and Absorbance and of undoped and doped CdO samples.

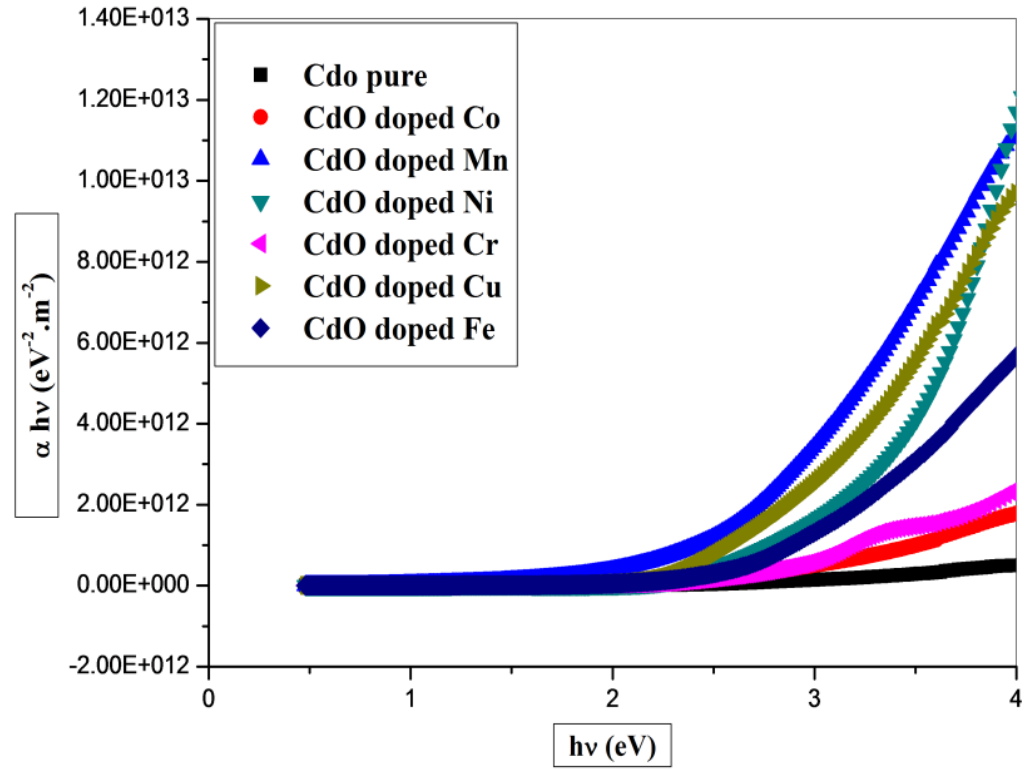

Fig. (3) The plots of $(\alpha h v)^{2} v$ s. photon energy of the undoped and doped CdO. 


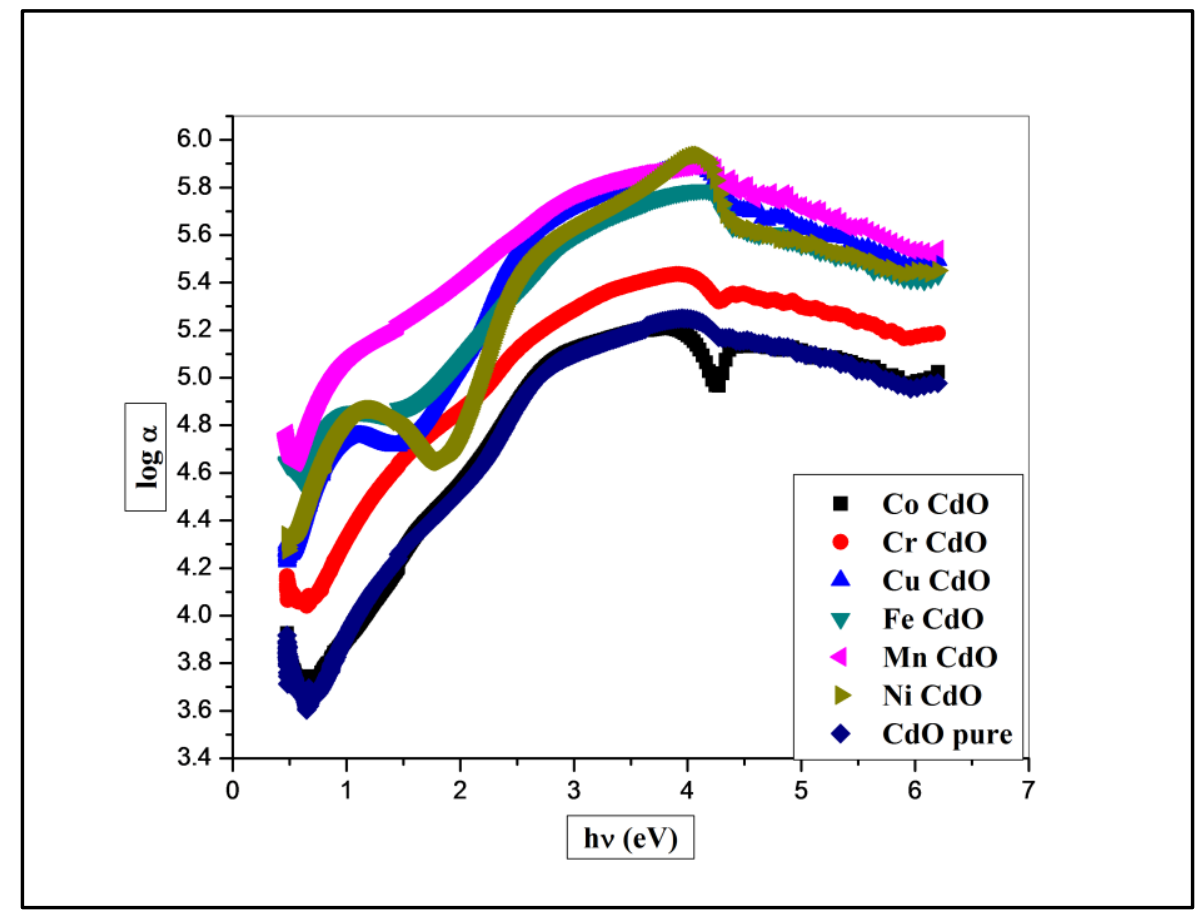

Fig. (4) Log $\alpha$ as a function of photon energy (hv)

Table (2) illustrates the values of band gap energy $\left(E_{g}\right)$ and the width of tails of the localized states in the gap.

\begin{tabular}{|c|c|c|c|}
\hline Sample & $\mathbf{E}_{\mathbf{g}}(\mathbf{e V})$ & $\mathbf{E}_{\mathbf{s}}(\mathbf{e V})$ & $\mathbf{E}_{\text {opt }}(\mathbf{e V})$ \\
\hline CdO & 2.33 & 1.865 & 1.98 \\
\hline Ni CdO & 3.016 & 1.112 & 1.91 \\
\hline Co CdO & 2.56 & 1.62 & 1.72 \\
\hline Cr CdO & 2.53 & 1.66 & 1.11 \\
\hline Cu CdO & 2.489 & 0.9515 & 1.679 \\
\hline Fe CdO & 2.57 & 1.85 & 1.46 \\
\hline MnCdO & 2.377 & 0.9227 & 1.34 \\
\hline
\end{tabular}

The refractive index dispersion plays an important role in the research for optical materials; it is a significant factor in optical communication and designing devices for spectral dispersion. The refractive index of the films was calculated according to the relation [Subrahamanyam, N.A., 1997], 


$$
n=(1+R) /(1-R)+\left(4 R /(1-R)^{2}\right)^{1 / 2}-K^{2}
$$

where $\mathrm{k}(\mathrm{k}=\alpha \lambda / 4 \Pi)$ is the extinction coefficient. Figure (5) gives the variation of refractive index with the wavelength.

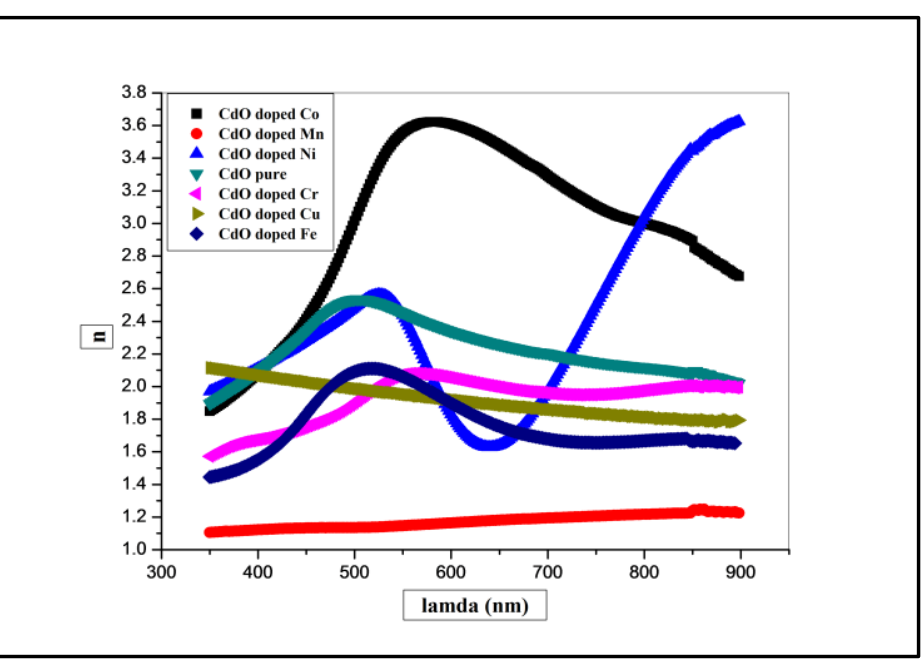

Fig.(5) the refractive index dependence of wavelength for the investigated films

Regarding $\mathrm{CdO}, \mathrm{Cr}$, $\mathrm{Co}$ and $\mathrm{Fe}, \mathrm{n}$ is observed to increase as hv increases to a point near to the value of $\mathrm{E}_{\mathrm{opt}}$, where it turns over and begins to decrease. In case of $\mathrm{Ni}$ and $\mathrm{Cu} \mathrm{n}$ is observed to decrease to a point lower than $\mathrm{E}_{\mathrm{opt}}$, where it turns over and begins to increase. Regarding $\mathrm{Mn}, \mathrm{n}$ is observed to decrease with energy.

The fundamental electron excitation spectrum of the films was described by means of a frequency dependent of the complex electronic dielectric constant. Real and imaginary parts of the dielectric constant are related to the $\mathrm{n}$ and $\mathrm{k}$ values. The $\varepsilon_{1}$ and $\varepsilon_{2}$ values were calculated using the formula [Moss, T.S. 1973],

$$
\begin{aligned}
& \varepsilon_{1}=n^{2}-k^{2} \\
& \varepsilon_{2}=2 n k
\end{aligned}
$$

Fig.6 (a,b) shows $\varepsilon_{1}$ and $\varepsilon_{2}$ values dependence on the photon energy (hv) 


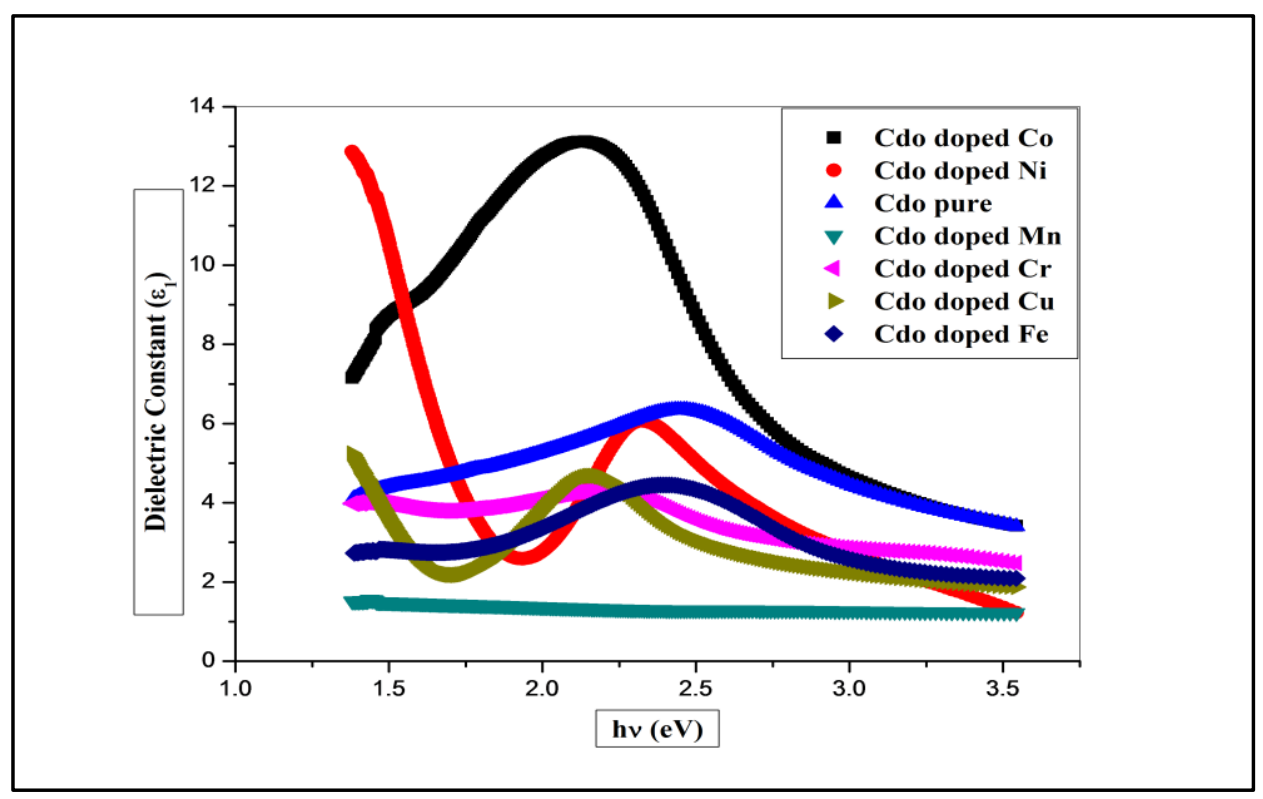

(a)

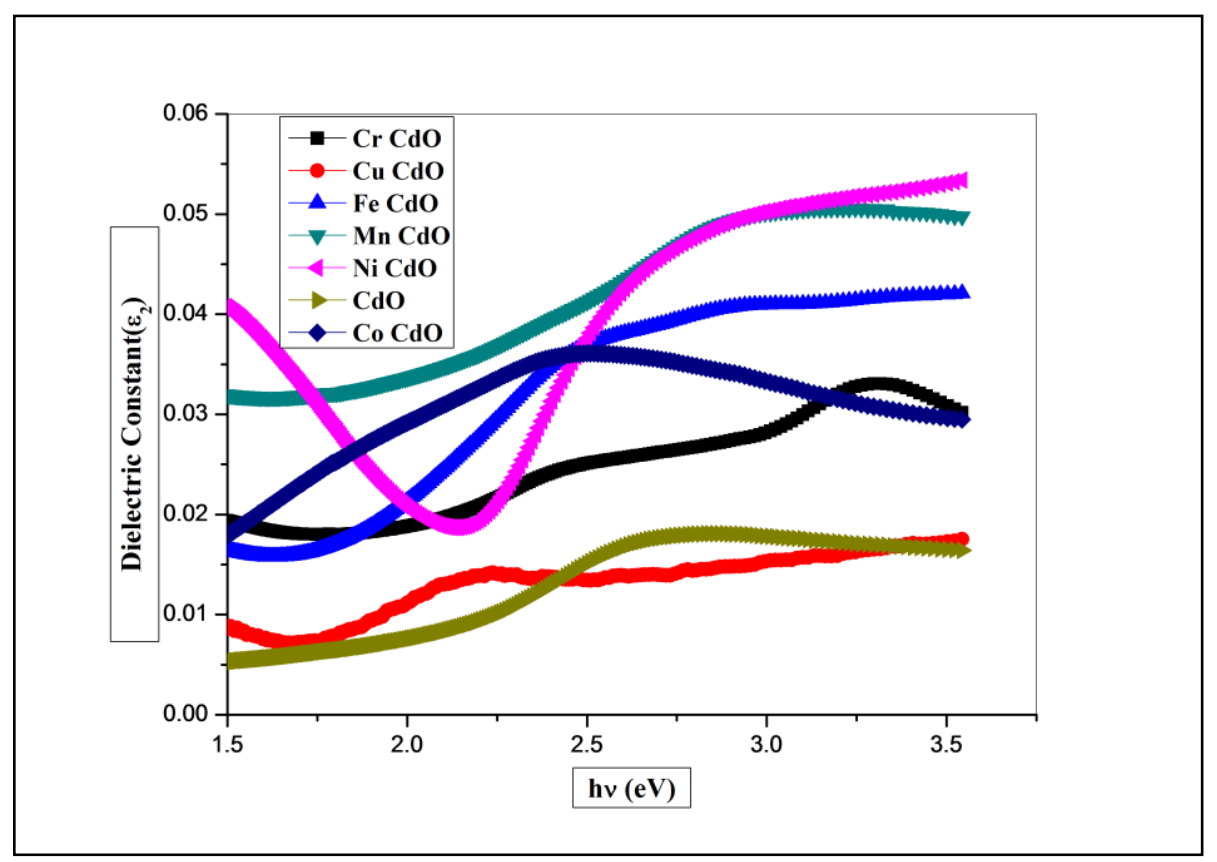

(b)

Fig.(6) (a) the dielectric constant $\left(\varepsilon_{1}\right)$ and (b) the dielectric loss $\left(\varepsilon_{2}\right)$ dependence on the photon energy (hv). 
From this figure clears the dielectric constant decreases with increasing photon From energy then increases and then decreases again with further increasing photon energy, except in case of $\mathrm{CdO}$ doped $\mathrm{Co}$ the dielectric constant increases then decreases with increasing of photon energy. However, the dielectric loss has constant values with increasing photon energy, but in case of $\mathrm{CdO}$ pure the dielectric loss increases with increasing photon energy, and except in case of $\mathrm{CdO}$ doped $\mathrm{Ni}$ dielectric loss decreases then increases with increasing photon energy.

The optical conductivity $\sigma_{\text {opt }}$ can be calculated by using the absorption coefficient $\alpha$ as in the following equation [Pankova, J.I., 1975]:

$$
\sigma_{\mathrm{opt}}=\frac{\alpha n c}{4 \pi}
$$

where $\mathrm{n}$ is the refractive index and $\mathrm{c}$ is the velocity of light. Fig .(7) shows the variation of the optical conductivity as a function of photon energy it is clear that the optical conductivity increases with increasing photon energy this may be due to the excitation of electrons by photon energy, and the optical conductivity increases with doping.

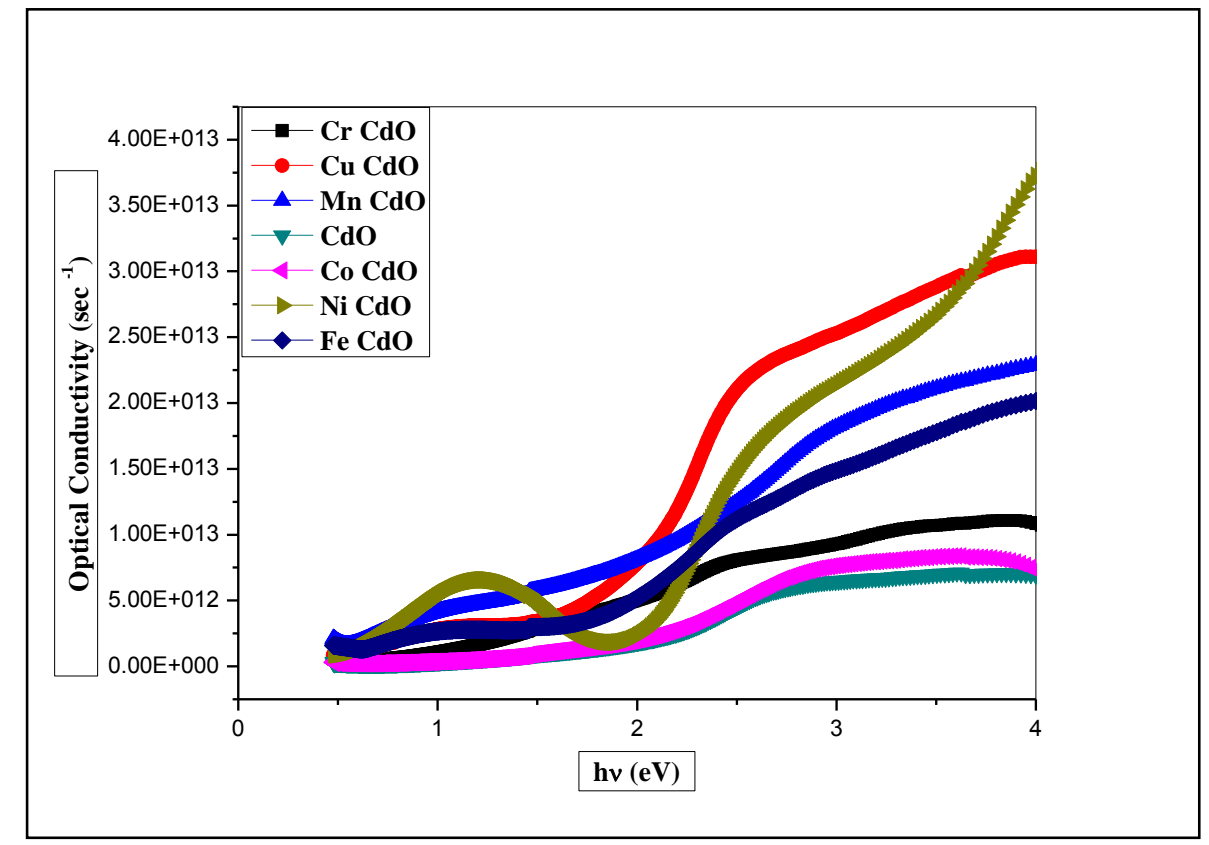

Fig. (7) The optical conductivity dependence on the photon energy for the investigated thin films.

\section{Conclusion}

Transition metals $(\mathrm{Cr}, \mathrm{Cu}, \mathrm{Co}, \mathrm{Ni}, \mathrm{Mn}$, and $\mathrm{Fe}$ ) doped $\mathrm{CdO}$ thin films were deposited on glass substrates using sol-gel spin coating method. X-ray diffraction patterns reveal the polycrtstalline structure of the prepared films, the obtained value of the grain size of $\mathrm{CdO}$ increased with doping with TM. 


\section{Reference:-}

Arean, C.Oetal.,J.Solid State Chem., 77, 272 (1988).

Barret, C.,Massalski,T.B., Structure of Metals, Pergamon, Oxford, P. 1923(1980).

Bhatti K. P., Chaudhary S., Pandya D.K. and Kashyap S.C., , "On the room- temperature ferromagnetism in $(\mathrm{ZnO})_{0.98}(\mathrm{Mn})_{0.02} \mathrm{O}_{2}$ ". Solid state Commun.136, 384-388, (2005).

Carballeda-Galicia DM., Castanedo-Perez R., Jimenez-Sandoval O., Jimenez-Sandoval S., Torres-Delgado G., Zuniga-Romero CI., , High transmittance $\mathrm{CdO}$ thin films obtained by the sol-gel method. Thin Solid Films 371,105, (2000).

Cimino A., Marezio M., Lattice parameter and defect structure of cadmium oxide containing foreign atoms. J. phys.Chem.Solids, 17, 57, (1960).

Crottaz O.,Kubel F., Kristallogr Z.,Crystal structure of copper (I) chromium (III) oxide, 2HCuCrO2.American Journal of Nano Research and Application211, 481,(1996).

DeokateRJ.,Pawar SM., Moholkar AV., Sawant VS., Pawar CA., Bhosale CH., Rajpure KY., Spray deposition of highly transparent fluorine doped cadmium oxide thin films. Appl.Surf.Sci,254 , 2187, (2008).

Ekambaram S., Yoichi Iikubo, Akihiko Kudo, J.Alloys\& compounds, 433, 237 (2006).

Ferrai, Colla, Gazz., American Mineralogist Crystal Structure Database. Chim.Ital. 65, 815, (1935).

Ferro R., Rodriguez J.A., Influence of F-doping on the transmittance and electron affinity of $\mathrm{CdO}$ thin films suitable for solar cells technology.Solar Energy Mater.and Solar Cells 64, $363,(2000)$.

Gurumurugan K., Mangalaraj D., NarayandassSa.K., Structural characterization of cadmium oxide thin films deposited by spray pyrolysisOriginal Research Article.Journal of Crystal Growth, Volume 147, Issues 3-4, 1 February, Pages 355-360,(1995).

Holland TJB and Redfern SAT, " the unit cell refinement from powder diffraction data: the use of regression diagnostic, 1997.

Kusigerski V., Spasojevic V., Synthesis and some physical properties of the diluted magnetic semiconductor Cd1-xMnxO.J. phys., Cadens Matter, 8, 10581, (1996).

Li L., Wang W., Lui H., Lui X., Song Q., RenS., , First principles calculations of electronic band structure and optical properties of Cr-doped $\mathrm{ZnO}$, The Journal of Physical Chemistry C , 113 (19), 8460-4, (2009). 
Lokhande B.J., Uplane M.D., Effect of deposition temperature on spray deposited cadmium oxide films. Mater. Res. Bull.36,439, (2001).

Matsuura N., Johnson D.J., Amm D.T., Fabrication of cadmium oxide thin films using the Langmuir-Blodgett deposition techniqueOriginal Research Article.Thin Solid Films, Volume 295, Issues 1-2, 28 February, Pages 260-265,(1997).

Maity R., Chattopadhyay K.K., Synthesis and characterization of aluminum-doped CdO thin films by sol-gel process. Sol. Energ. Mater.Sol. Cell 90, 597, (2006).

Moss T.S., Burrell G.J., Ellis B., Semiconductor Opto-Electronics, Wiley, New York, (1973).

Muralia K.R., Kalaivananb A., Perumalc S., NeelakandaN. Pillaic, Sol-gel dip coated CdO:Al films. Journal of Alloys and Compounds503, 350, (2010).

Mustafa Öztas, MetinBedir, Thickness dependence of structural, electrical and optical properties of sprayed ZnO:CufilmsOriginal Research Article. Thin Solid Films, Volume 516, Issue 8, 29 February, Pages 1703-1709, (2008).

Ortega M., Santana G., A. Moroles A. Acevedo, Optoelectronic properties of $\mathrm{CdO} / \mathrm{Si}$ photodetectors.Solid State Electron44, 1765, (2000).

Pankova, J.I., Optical Processes in Semiconductors, Dover Publications Inc., New York, P.91, (1975).

Pankova J.I., Optical Processes in Semiconductors, Prentice-Hall Inc., Englewoord Cliffs, NJ, (1971).

Qian,Y., et al., Univ. Of Science's Technology of China, Hefi, Anhui, People's Repulic of China, Private Communication (1994).

Ramakrishna Reddy K.T., Sravani C., Miles R. W., Characterisation of CdO thin films deposited by activated reactive evaporation. J. Cryst. Growth, 184-185, 1031, (1998).

Subrahamanyam N.A., A text book of Optics, 9 ed.: Brj. Laboratory, Delhi, India,(1977).

Subramanyam T.K., Uhanna S., Srinivasula B. Naidu, Preparation and characterization of CdO films deposited by dc magnetron reactive sputtering.Mater.Latt.35,214, (1998).

Vasambekar P., Dept. of Electronics, Shivioji Univ., Kolhpur, India, Private Communication, (2001).

Volbers N., Zhou H., Knies C., Pfisterer D., Sann J., Hofmann D., Meyer B.K., , synthesis and characterization of $\mathrm{ZnO}$ : $\mathrm{CO}$ nanoparticles. Applied physics A: Materials Science \&amp; Processing 88 (1), 153-5, (2007). 
Weast R.C., Handbook of Chemistry and Physics, 56 thedn, CRC Press, Cleveland, Cleveland, 19760, 1975.

Zhiyong Zhao, Morel D.L., Ferekides C.S., Electrical and optical properties of tin-doped CdO films deposited by atmospheric metal organic chemical vapor deposition Original Research Article. Thin Solid Films Volume 413, Issues 1-2, 24 June, Pages 203-211, 2002.

\author{
الملخص العربي \\ دراسة الخواص البلورية والضوئية لاكاسيد الكاديوم المطعمة ببعض العناصر الانتقالية المحضرة بطريقة السول جل
}

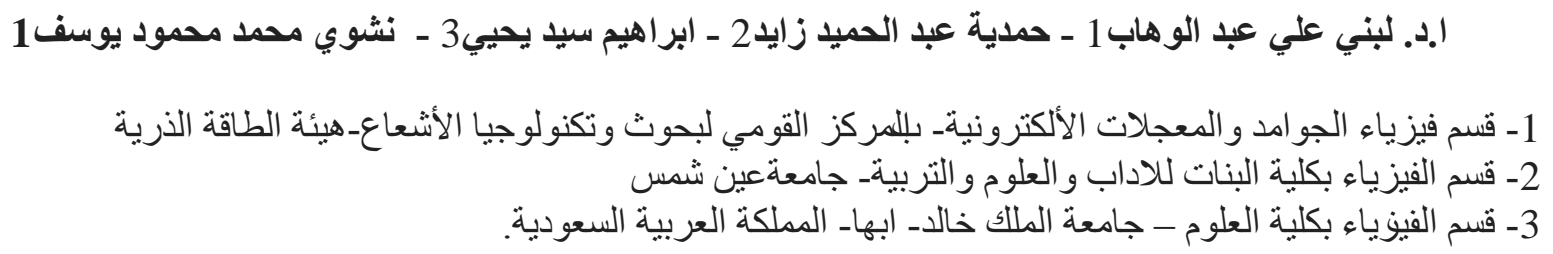

اكاسيد الكاديوم النانومثرية المطعمة ببعض العناصر الأنقالية ( الكروم ، النحاس، الحديد ، النيكل، المنجنيز، الكوبالت)

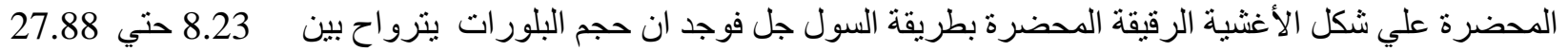

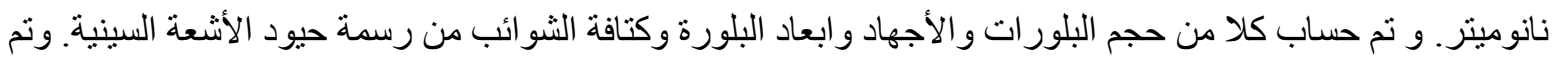
حساب قيمة الفجوة وجد انها في حدود 2.302 الكترون فولت لاكسيد الكاديوم النقي و تزيد قيمة الفجوة مع اضافة الفية العناصر 